\title{
Evaluation of the Barrier-Free Tourism and Sustainability of the Barrier-Free Society in Cyprus
}

\author{
By Fahriye Altinay ${ }^{1}$, Zehra Altinay ${ }^{1}$, Mehmet Altinay ${ }^{2}$, Gökmen Dagli ${ }^{3}$
}

\begin{abstract}
The main aim of the current study is to evaluate the opinions of the students at the departments of tourism and special education towards to the concept of sustainability of barrier-free tourism and society therefore with the light of this aim, and current study attempted to address how disabled individuals could have an access to the tourism and life opportunities as well as the challenges that they are experiencing while having an access to these opportunities, probable solutions which might be employed to cope with these challenges, universal rights of the disabled individuals about having an access and transportation in contexts barrier-free tourism practices in TRNCThe current study employed a semi-structured interview as a data collection tool. The study group of the current research consisted of 80 participants who are the students at the tourism and specialized education teaching departments at Near East University and the University of Kyrenia. Data were collected with 20 minutes face to face interviews. While performing data analysis, responses of the participants were categorized and placed to the tables and then the researcher(s) re-examined the classified data set and formed underlying themes and categories. With the light of the findings, it can be stated that education at universities, secondary and primary schools should be intensified to inject necessary information to the students regarding barrier free tourism and provision of health care services for disabled people. At the reffered point. joint commitment should be carried among ministry of education, tourism, heallth and municipalities to raise public awareness regarding barrier free tourism. Additionally media and press should design more programs regarding barrier free tourism at their broadcasting stream to raise public awareness, and in-service trainings for disabled people should be provided to employees in hotels.
\end{abstract}

Keywords: Barrier-Free Tourism, Sustainable Society, Education, Accessibility, Awareness

\section{Introduction}

Sustainability is a critical success factor for revamping and making development. It is essential to internalize the merits of accessibility within society. To provide services in all levels of ages and all levels of education, the community needs awareness on universal values to integrate social justice and equality. In respect, raising the understanding of barrier-free services in terms of equality, accessibility plays a significant role in fostering sustainable services in societies (Karaatmaca, Altinay, Altınay, 2019).

The term smart society focuses on all levels of education and services to people by the merits of information technology and pays attention to provide services accessible, inclusive, and also equal for social involvement and justice for everyone. Therefore, tourism is a needed field for people for social participation and requires service for everyone. It is essential to foster services in tourism to socialize with everyone, even 
disabled people. Making tourism services for everyone and establishing facilities for everyone is the stance of barrier-free tourism to create a barrier-free society as a smart society (Bastas, Altinay, 2019).

World Health Organization (WHO) defined disability as a disadvantageous situation that occurs in forms of limiting or losing the ability to perform any activity when compared with a non-disabled person. Needless to indicate that the concept of disability could be regarded as a fact of life and it could be articulated that people could encounter limitation at different phases of their lives, in terms of loss of movement functions at their various parts of their body either temporarily or permanently due to number of several reasons which in turn creates challenges at daily routines of the people ( Turkey Disability Research, 2018). Besides these, the concept of disability could be examined under seven dimensions, namely vision, mental, orthopedic, language and speech, hearing, chronic illnesses, and lastly, mental and emotional (World, Disability Report, 2011).

Furthermore, it can be outlined that that smart living spaces are booming day by day, and they provide various opportunities to disabled individuals, such as giving them chances to become more active in social life as well as satisfy their daily needs without experiencing any difficulties. Apart from these, it is believed that advancements at information and communication technologies had enabled disabled individuals at different locations to take benefits from efficient and influential communication which would stimulate transparency as well as create necessary decision-making mechanisms, particularly in contexts of public and administrative practices. Therefore, from this perspective, it can be signaled that tourism services are playing a prominent role in generating a sustainable barrier-free society (Altınay, Dağlı, Altınay, and Altınay, 2019).

The main aim of the current study is to evaluate the opinions of the students at the departments of tourism and special education towards to the concept of sustainability of barrier-free tourism and society therefore with the light of this aim, and current study attempted to address how disabled individuals could have an access to the tourism and life opportunities as well as the challenges that they are experiencing while having an access to these opportunities, probable solutions which might be employed to cope with these challenges, universal rights of the disabled individuals about having an access and transportation in contexts barrier-free tourism practices in TRNC.

\section{Methodology}

\subsection{Research Model}

The qualitative research model was appointed for the current study. From the past to the present, several practitioners had defined the term of the qualitative research model. For instance, Yıldırım and Şimşek (2011) had stressed qualitative research methods which may constitute from several data collection techniques including observation, interview as well as document analysis for exploring perceptions and events at their natural environment by following realistic and holistic principles during the data collection process. Some scholars attempted to lament the characteristics of the qualitative research model. For instance, Kuş (2003) had stressed that one of the crucial aspects of the qualitative research models as creating chances for the practitioners to advance their perceptions regarding the perspectives of the respondents about research field as well as 
it is also generating better understanding to the practitioners through the eyes of the respondents regarding how they are evaluating the meaning of the world.

\subsection{Data Collection Tools}

The current study employed a semi-structured interview as a data collection tool. Legard, Keegan, and Ward (2003) articulated that in-depth interviews (face to face), direct observation and document analysis are popular techniques which are employed to collect data for qualitative research methods. Besides of these, it could be signified that face to face interview technique which allows researchers to deepen their understanding about the perspectives of the participants as well as face to face interview technique could be beneficial to extract emotions, feelings, dimensions and lastly dimensions which played a significant role at the responses of the participants.

Asides from these, face to face interview technique is appointed, particularly when it is challenging for the researcher(s) to conduct direct observation during the qualitative research process (Legard et al, 2003). It could be a signified semi-structured interview form was consisted of four open-ended questions to obtain the responses of the participants. In addition to all these, the researcher(s) preferred to use voice recorders as a voluntary basis to halt losing data during the interview process.

Furthermore, researchers of the current study had submitted the form to the academicians who are lecturing in the Faculty of Education Sciences department at Near East University to have their expert opinion for enhancing the internal validity of the data collection tools. Researchers of the current study had redesigned the form with the light of the suggestions of the academicians and then conducted a pilot study to examine whether the questions are clear and understandable to respondents as well responses which provided by the respondents are compatible with the questions which were asked to them by the researchers. Moreover, experts at education management and Turkish Language had also articulated recommendations to the researchers while designing the semi-structured interview questions about the context of the questions. Then researchers had initiated the data collection process from the respondents. Content analysis was executed to transcribe the findings of the current study.

\subsection{Study Group}

It could be stated that a study group of the current research consisted of 80 participants who are the students at the tourism and specialized education teaching departments at Near East University and the University of Kyrenia.

\subsection{Data Collection Process}

Participants were informed regarding the aim, data collection procedure and lastly data collection method of the study. In addition to this, it could be mentioned that respondents who were included in the study group determined with the light of a voluntary basis. Then researchers of the study had adjusted appointments with the participants before the data collection period. It may be expressed that data collection started in December 2019 and it took around 20 minutes to obtain data from each participant through face to face interviews.

Researchers expressed privacy ethics to the chairs of the departments and then obtained 
necessary permissions for using voice recorders during the data collection process. In addition to the voice recorders, opinions of the participants were noted by researchers to block any confusion which might occur during the process of data collection.

\subsection{Data Analysis}

While performing data analysis, responses of the participants were categorized and placed to the tables and then the researcher(s) re-examined the classified data set and formed underlying themes and categories. The themes and categories were also analyzed with the light of the relevant literature and those themes and categories which are compatible with the relevant literature were integrated while different codifications had been formed for the themes and categories which were not matching with the relevant literature.

\section{Results and Interpretations}

Dimension 1: Opinions of the respondents about the practices employed for the access of disabled individuals in the context of barrier-free tourism and life opportunities Opinions of the respondents about the practices employed for the access of disabled individuals in the context of barrier-free tourism and life opportunities are summarized as percentages $(\%)$ and themes by Table 1 .

Table 1: Opinions of the respondents about the practices employed for the access of disabled individuals in the context of barrier-free tourism and life opportunities

\begin{tabular}{|c|c|c|}
\hline Themes & Frequency & Percentage $\%$ \\
\hline $\begin{array}{l}\text { In TRNC, tourism and living opportunities are regarded as inadequate since } \\
\text { disabled people are encountering difficulties to have access to them }\end{array}$ & 75 & $\% 93$ \\
\hline $\begin{array}{l}\text { The opportunities which declared to the disabled individuals as written form } \\
\text { were different than the possibilities which provided to them for their daily life }\end{array}$ & 70 & $\% 87$ \\
\hline Participation of disabled people to public life is too limited & 60 & $\% 75$ \\
\hline $\begin{array}{l}\text { In TRNC, hotels have only a limited number of rooms as well as poorly } \\
\text { equipped swimming pools and/or beaches for disabled people }\end{array}$ & 72 & $\% 90$ \\
\hline Hotels are not practicing a discount policy for low-income disabled people. & 54 & $\% 67$ \\
\hline $\begin{array}{l}\text { Disabled people are missing a chance to have a holiday since no transportation } \\
\text { services are designed to facilitate their access. }\end{array}$ & 68 & $\% 83$ \\
\hline $\begin{array}{l}\text { Starting from primary school, seminars should be arranged to stress that } \\
\text { disabled people have equal rights and living conditions in the context of barrier- } \\
\text { free tourism }\end{array}$ & 73 & $\% 91$ \\
\hline $\begin{array}{l}\text { Education and or training programs should be designed particularly for the } \\
\text { families in the context of barrier-free tourism to elevate awareness of them }\end{array}$ & 56 & $\% 70$ \\
\hline Raising awareness with technology-supported presentations and visuals & 45 & $\% 56$ \\
\hline
\end{tabular}

In order to assess the sustainability of barrier-free society within the scope of barrier-free tourism, a participant in the condition of application for the access of disabled people with barrier-free tourism and life opportunities said, "In our country, I would like to make it clear that the access of individuals with disabilities is generally inadequate in terms of tourism and life opportunities." (G(54)), he expressed his opinion. Another participant said, "I find it very helpful to say that the number of rooms that hotels for the disabled are very small and inadequate on our island and that pools or seas do not have the necessary equipment for the benefit of the disabled." (G34)), they expressed 
their views. Another participant said, "I would like to make it clear that seminars that inform people of disabilities have equal rights and living conditions within the scope of barrier-free tourism should be put in programs starting from the preschool period." (G(22)), he expressed his opinion. Another participant said, "I would like to make it clear that more children with disabilities can be helped if education programs for families are increased further within the scope of barrier-free tourism." (G:(78)) expressed his opinion. Depending on the findings, the programs of seminars that inform disabled people have equal rights and living conditions in barrier-free tourism in order to assess the sustainability of barrier-free society within the scope of barrier-free tourism can be said to be put in the beginning. Also, the number of rooms reserved by hotels for the disabled is minimal and inadequate in our island and the necessary reduction in hotel prices for low-income people, where pools or seas do not have the necessary equipment for the benefit of the disabled it is understood that there are no opportunities to holiday because it is not made and transportation facilities for the benefit of the disabled are not facilitated. Besides, it can be said that more aid can be provided to children with disabilities if education programs for families are increased further within the scope of barrier-free tourism.

Dimension 2: Problems encountered by disabling people in the context of tourism and living opportunities and probable solutions and opinions regarding access and transportation.

Opinions of the respondents are regarding dimension 2 were summarized as percentages $(\%)$ and themes by Table 2 .

Table 2: Problems encountered by disabling people in the context of tourism and living opportunities and probable solutions and opinions regarding access and transportation.

\begin{tabular}{|c|c|c|}
\hline Themes & Frequency & $\begin{array}{l}\text { Percentage } \\
\%\end{array}$ \\
\hline $\begin{array}{l}\text { Providing supervision and enforcement practices for the related institutions, } \\
\text { Provision of incentives in case of necessity }\end{array}$ & 55 & $\% 68$ \\
\hline $\begin{array}{l}\text { Taking necessary measures to design rooms, lavatories, elevators for facilitating } \\
\text { daily activities of the disabled people at public enterprises and areas., }\end{array}$ & 47 & $\% 58$ \\
\hline $\begin{array}{l}\text { "Right for equal access for everyone" message should be disseminated without } \\
\text { isolating disabled people, }\end{array}$ & 49 & $\% 61$ \\
\hline $\begin{array}{l}\text { Hotels which benefited from the incentives should be monitored with the light of } \\
\text { criterion to ensure that they provided necessary policies to become accessible for } \\
\text { disabled people }\end{array}$ & 24 & $\% 30$ \\
\hline Buses and restaurants should be equipped to provide services for disabled & 37 & $\% 46$ \\
\hline people, & 69 & $\% 86$ \\
\hline $\begin{array}{l}\text { Municipalities should advance their sensitivity to offer better services for disabled } \\
\text { people. }\end{array}$ & 65 & $\% 81$ \\
\hline $\begin{array}{l}\text { Cities should be designed to facilitate the daily routines of the disabled people, } \\
\text { Sidewalks, ramps, and passages should be constructed in a way to promote daily } \\
\text { routines for disabled people. }\end{array}$ & 78 & $\% 97$ \\
\hline
\end{tabular}

A participant, to assess the situation regarding the sustainability of society without barriers within the frame of unimpeded tourism, considering the problems and the possible solutions, which the disabled persons experience and the status of access and transportation concerning touristic and lively utilities, states that "I would like to remark that the audits carried out and sanctions imposed by the relevant authorities in our country is inadequate 
$(G(44))$." Another participant, regarding the same theme, also states that "I find it pretty beneficial to emphasize that serious measures should be taken to ensure that the assisted facilities for disabled persons such as disabled-friendly rooms, disabled assisted elevators, disabled assisted toilets which usually is built in public areas/buildings only for granting the necessary permissions, are being used only for the purpose which it fits (G31)). "A third participant again states that, "I would like to highlight that a serious level of criterion should be set for the facilities that enjoy subsidy in order to ensure that these facilities would be accessible for the disabled persons." (G(72)) Another participant, with regards to the same theme, states that "I would like to underline that there should be made disabled-friendly buses for transportation and restaurants, also I would like to clearly state that local governments' approach to disabled persons should be on a higher level."(G:(18)) According to the findings of the survey, to assess the situation regarding the sustainability of society without barriers within the frame of unimpeded tourism, one can say that relevant authorities should carry out audits and impose sanctions, entities should be subsidized if necessary, serious measures should be taken to ensure that the assisted facilities for disabled persons such as disabled-friendly rooms, disabled assisted elevators, disabled assisted toilets which usually is built in public areas/buildings only for granting the necessary permissions, are being used only for the purpose which it fits. Also it should be guaranteed that disabled persons should benefit from "right to equal access for everybody" without any discrimination/isolation, a serious level of criterion should be set for the facilities that enjoy subsidy to ensure that these facilities would be accessible for the disabled persons and there should be made disabledfriendly buses for transportation and restaurants. Also, one can say that cities should be designed for disabled persons by building sidewalks and platforms for disabled persons.

Dimension 3: Results regarding the provision of education to elevate the success of barrier-free tourism and sustainability in TRNC

Results regarding the provision of education to elevate the success of barrier-free tourism and sustainability in TRNC are illustrated in table 3.

Table 3: Results regarding the provision of education to elevate the success of barrier-free tourism and sustainability in TRNC

\begin{tabular}{|c|c|c|}
\hline Themes & Frequency & $\begin{array}{c}\text { Percentage } \\
\%\end{array}$ \\
\hline $\begin{array}{l}\text { Education at universities, secondary and primary schools should be intensified to } \\
\text { inject necessary information to the students regarding barrier-free tourism and } \\
\text { provision of health care services for disabled people }\end{array}$ & 48 & $\% 60$ \\
\hline $\begin{array}{l}\text { Joint commitment should be carried among the ministry of education, tourism, } \\
\text { health, and municipalities to raise public awareness regarding barrier-free tourism, }\end{array}$ & 49 & $\% 61$ \\
\hline $\begin{array}{l}\text { Media and press should design more programs regarding barrier-free tourism at } \\
\text { their broadcasting stream to raise public awareness, }\end{array}$ & 54 & $\% 67$ \\
\hline In-service training for disabled people should be provided to employees in hotels, & 62 & $\% 77$ \\
\hline Web accessibility should be improved for the visually and hearing impaired, & 31 & $\% 38$ \\
\hline Elevating the quality of education, & 50 & $\% 62$ \\
\hline $\begin{array}{l}\text { Injecting necessary knowledge at the universities particularly to the architecture } \\
\text { students regarding universal design principles through different courses as well as } \\
\text { while educating future architects, to raise their awareness regarding their } \\
\text { profession; the importance of designing barrier-free spaces both at urban and } \\
\text { architectural scale should be explained to them since it is part of both their } \\
\text { professional career and responsibilities at institutional and individual basis }\end{array}$ & 27 & $\% 33$ \\
\hline Each institution and individuals should focus more on designing social & 39 & $\% 48$ \\
\hline
\end{tabular}




\begin{tabular}{|c|c|c|}
\hline Themes & Frequency & $\begin{array}{l}\text { Percentage } \\
\%\end{array}$ \\
\hline \multicolumn{3}{|l|}{$\begin{array}{l}\text { responsibility projects about barrier-free tourism as well as should pay more } \\
\text { attention to shape their efforts and resources properly in the context of barrier- } \\
\text { free tourism, }\end{array}$} \\
\hline $\begin{array}{l}\text { Universities should conduct more scientific studies in the context of barrier-free } \\
\text { tourism. }\end{array}$ & 65 & $\% 81$ \\
\hline $\begin{array}{l}\text { Provision of training to all members who are active at associations (which are } \\
\text { providing services for disabled people) will be helpful to advance their } \\
\text { understanding regarding the criteria of the accessibility on tourism field to } \\
\text { provide them an insight for questioning tourism organizations under these criteria }\end{array}$ & 28 & $\% 35$ \\
\hline $\begin{array}{l}\text { Building a commitment with associations that are providing services to the } \\
\text { disabled people and establishing collaboration with specialized education centers } \\
\text { will enhance the effectiveness of the courses taught at Special Education Teaching } \\
\text { departments. }\end{array}$ & 66 & $\% 82$ \\
\hline $\begin{array}{l}\text { Provision of intensified and influential education regarding topics such as barrier- } \\
\text { free tourism in primary and secondary schools as well at universities and } \\
\text { constructing collaboration among municipalities, press, and media will elevate the } \\
\text { empathy skills of the community regarding barrier-free tourism. }\end{array}$ & 71 & $\% 88$ \\
\hline $\begin{array}{l}\text { Universities should be sensitive about putting efforts towards to adapt } \\
\text { themselves for the barrier-free campus criteria }\end{array}$ & 63 & $\% 78$ \\
\hline Activation of the barrier-free house project & 25 & $\% 31$ \\
\hline $\begin{array}{l}\text { More master and doctorate studies should be conducted in education faculties to } \\
\text { lament the importance of the social responsibility aspect. }\end{array}$ & 45 & $\% 56$ \\
\hline $\begin{array}{l}\text { More research and development activities should be conducted at special } \\
\text { education centers. }\end{array}$ & 26 & $\% 32$ \\
\hline
\end{tabular}

One participant in the introduction of education in Cyprus as part of the successful impeded tourism and sustainability in order to assess the viability of the community without barriers in the form of barrier-free tourism, "I would like to state clearly that education in universities, primary and secondary education should be improved by offering disabled people specific lessons in tourism and health services." (G (33)), expressed his view. Another participant is concerned with this theme and expresses their opinions by saying "I think it is very beneficial to say that, one of the tasks and responsibilities, both institutionally and individually, will be to raise awareness among students, particularly in the course content of architectural faculties, to raise awareness among students in different courses and to build an unbroken space both on an urban and architectural scale, especially when educating future architects." $(\mathrm{G}(43))$. Another participant said, "I want to express the need to provide all members of the disabled associations with accessibility education in the field of tourism so that they can challenge these businesses based on certain criteria wherever they go" (G (12)). Another participant shared his views on this subject as "I would like to state clearly that studies which include the dimension of social responsibility in master's and doctoral studies in educational faculties" (G: (48)). On the basis of the findings, it could be said that required to be done to determine the sustainability of society without barriers within the scope of barrier-free tourism, developing education by giving serious lessons on' disabled tourism' and' disabled health services' to university, primary and secondary education students, cooperating with the Ministry of Education, the Ministry of Tourism, the Ministry of Health and all municipalities to raise public awareness, every day publishing a certain program for disabled tourism to raise public awareness through every media, press and broadcasting organs, providing in-service training for disabled people to hotel staff, developing web 
accessibility for visual and hearing impaired people, raising awareness among universities, particularly in architectural faculties, in case universal design principles are transferred to students with different courses, awareness raising that creating an unimpeded space on both an urban and an architectural scale will be a natural part of the design, particularly when training future architects, giving more weight to the studies required in the areas of unobstructed tourism within the scope of social responsibility projects by using the facilities of each institution and individual properly and adequately, higher use of these subjects in scientific studies among universities, providing all members of the disabled associations with accessibility education in the field of tourism so that they can challenge these businesses on the basis of certain criteria wherever they go, cooperating more closely with disability associations and special education centers for practical purposes in Special Education Teaching courses in Education Faculties.

\section{Conclusions and Suggestions}

Dimension 1: Results regarding opinions of the respondents about the practices employed for the access of disabled individuals in the context of barrier-free tourism and life opportunities.

With the light of the findings, themes such as "starting from the primary school, seminars should be arranged to stress that disabled people have equal rights and living conditions in context of barrier-free tourism" (Karaatmaca et al., 2019), "In TRNC, hotels have only limited number of rooms as well as poorly equipped swimming pools and beaches for disabled people"," hotels are not practicing a discount policy for low-income disabled people"," disabled people are missing a chance to have a holiday since no transportation services are designed to facilitate their access," "the opportunities which declared to the disabled individuals as written form was different than the opportunities which provided to them for their daily life", "participation of disabled people to the public life is too limited"(Baştaş and Altınay, 2019) are representing respondents' opinions about the practices which employed for the access of disabled individuals in context of barrier-free tourism and life opportunities.

Dimension 2: Results regarding problems encountered by disabled people in the context of tourism and living opportunities and probable solutions and opinions regarding access and transportation.

In line with the aim of the current study, respondents are requested to articulate their opinions regarding problems encountered by disabled people in the context of tourism and living opportunities and probable solutions and opinions regarding access and transportation.

Respondents outlined that "providing a supervision and enforcement practices for the related institutions", "provision of incentives in case of necessity"," "taking necessary measures to design rooms, lavatories, elevators for facilitating daily activities of the disabled people at public enterprises and areas"(Altınay et al, 2019), "right for equal access for everyone" message should be disseminated without isolating disabled people", hotels which benefited from the incentives should be monitored with the light of criterion to ensure that they provided necessary policies to become accessible for disabled people"," buses and restaurants should be equipped to provide services for the disabled people", 
"cities should be designed to facilitate daily routines of the disabled people"," sidewalks, ramps, and passages should be constructed in a way to facilitate daily routines for the disabled people" could be helpful to minimize the challenges that disabled people may experience in context of tourism and living opportunities as well as their access and transportation.

Dimension 3: Results regarding the provision of education to elevate the success of barrier-free tourism and sustainability in TRNC

Opinions and suggestions of the participants regarding dimension 3 are indicated as follows;

Education at universities, secondary and primary schools should be intensified to inject necessary information to the students regarding barrier free tourism and provision of health care services for disabled people, joint commitment should be carried among ministry of education, tourism, heallth and municipalities 000to raise public awareness regarding barrier free tourism, media and press should design more programs regarding barrier free tourism at their broadcasting stream to raise public awareness, in-service trainings for disabled people should be provided to employees in hotels (Saner, Altinay, Altınay and Bahçelerli, 2019), web accessibility should be improved for the visually and hearing impaired, injecting necessary knowledge at the universities particularly to the architecture students regarding universal design principles through different courses as well as while educating future architects, to raise their awareness regarding their profession; the importance of designing barrier-free spaces both at urban and architectural sc0ale should be explained to them since it is part of both their professional career and responsibilities at institutional and individual basis, each institution and indviduals should focus more on designing social responsibility projects about barrier free tourism as well as should pay more attention to shape their efforts and resources in a proper manner in context of barrier free tourism, provision of training to all members who are active at associations (which are providing services for disabled people) will be helpful to advance their understanding regarding the criteria of the accessibility on tourism field to provide them an insight for questioning tourism organizations under these criteria and lastly building a commitment with associations which are providing services to the disabled people and establishing colloboration with special education centers will enhance the effectiveness of the courses which taught at Special Education Teaching departments (Karasel, Altınay, Dağlı and Altınay, 2018).

\section{References}

Altınay, F., Dagli, G., Altinay, M., Altinay, Z. (2019). The Role of Technology in Tourism and Health Services for Accessibility in Service Management" (Art.Code. LUM_1242), Journal POSTMODERN OPENINGS, 10(4), 1-7. .DOI: http://dx.doi.org/10.18662/po/90

Bastas, M \& Altinay, Z. (2019) Employment for Disability: Human Resources Management in Higher Education for Quality, International Journal of Disability, Development and Education, 66:6, 610615, DOI: 10.1080/1034912X.2019.1643456

Karaatmaca, C. Altinay, Z. , Altınay, F. (2019). Suggestions for Improving the Country's Master Plan for the Disabled People with Life-Sustaining Limitations. Brain-Broad Research in Artificial Intelligence And Neuroscience, 10(2)000 93-1021 
Karasel N \& Altınay, F \& Dagli,G. \& Altınay, Z. 2018. "An investigation of universal values and disability awareness in course books," Quality \& Quantity: International Journal of Methodology, Springer, vol. 52(2), pages 1235-1243, December. DOI: 10.1007/s11135-018-0693-x

Kuş, E. (2003). Nicel-nitel araștirma teknikleri. Ankara: Anı Yayıncilık.

Legard,R.,Keegan,J. \& Word, K. (2003). In-depth interviews.Ritchie \& J. Levis, J.(Edit.). Qualitiative resarch practices.London:Sage publication.

Miles, M. B., Huberman, A. M. (1994). Qualitative data analysis: An expanded sourcebook (2nd ed.). California: Sage. Saner, T., Altinay, Z., Altinay, F., \& Bahçelerli, N.M. (2019). The Role of Technology in Creating Job Opportunities for Learners with Disabilities in the Tourism Industry. Brain-Broad Research in Artificial Intelligence And Neuroscience Volume: 10 Issue: 1 Pages: 137-140

Turkey Disability Research,,2018) http://www.ehy.gov.tr/tr/8245/Türkiye-EngellilerAraştırması-TemelGöstergeleri\#oran

World Disability Report, (2011). World Health Association, 2011.

Yıldırım, A., ve Şimşek, H. (2011). Sosyal Bilimlerde Nitel Araștırma Yöntemleri. Ankara: Seçkin Yayıncılık. 